\title{
Is Eurocentrism a European Problem? Decolonial Meditation in Twenty Theses
}

\section{Rita Segato}

\section{(2) OpenEdition \\ Journals}

Electronic version

URL: http://journals.openedition.org/transtexts/1273

DOI: $10.4000 /$ transtexts. 1273

ISSN: 2105-2549

\section{Publisher}

Gregory B. Lee

Electronic reference

Rita Segato, "Is Eurocentrism a European Problem? Decolonial Meditation in Twenty Theses », Transtext(e)s Transcultures 跨文本跨文化 [Online], 14 | 2019, Online since 31 December 2019, connection on 28 July 2020. URL : http://journals.openedition.org/transtexts/1273 ; DOI : https:// doi.org/10.4000/transtexts. 1273

This text was automatically generated on 28 July 2020 .

(c) Tous droits réservés 


\title{
Is Eurocentrism a European Problem? Decolonial Meditation in Twenty Theses
}

\author{
Rita Segato
}

\section{EDITOR'S NOTE}

This aphorismatic text was presented, by invitation, at the encounter of directors of European Museums “Europe of Museums," Centre Pompidou, 8 April 2019.

I am absolutely astonished,

HOW EUROCENTRISM AFFECTS EUROPE?

This is a question unheard of before

\section{I had spent hours explaining}

how eurocentrism affects us, Latin Americans, not you, Europeans.

But, indeed, it really affects you,

your imagination, your intelligence.

I. From a decolonial point of view Europe is the consequence of the emergence of the entity America in the grid of a new organization of the world and subjectivity after the conquest and colonization. America gives birth to Europe, to Modernity, to Capitalism, and to the racial classification of people and geopolitics. The Indian, the Black and the White are born the same day, says Aníbal Quijano, in what he calls the reoriginalization of the world after America's appearing in the map.

II. From that new epistemic grid, Europe has to enthrone itself with reference to its others. And more than that, it must foreclose its origin, the very process of its emergence. 
III. All humankind becomes then the other of Europe, where to be the other of Europe turns into being an anomaly, a deviance of the universal subject, a residue of the true political agora, a minority.

IV. The very organization of topics into universal issues and minority issues, which is undoubtedly scandalous, comes from the enshrinement of Europe as humankind, the capture of Humankind from Europe.

I have been saying to feminists everywhere: yielding to the minoritization was a terrible mistake.

But that mistake was a consequence of the universalization of Europe: the center, the normal, the political, and its others.

V. Modernity is a great machine for producing minoriticized anomalies of every kind, anomalies that have to be filtered through the grid of universal reference and, using the language of multiculturalism, reduced, typified, and classified as iconized political identities in order to be reintroduced into the public sphere in their new, and only this, form. Anything that cannot be adapted to this exercise, that cannot be made to fit into the matrix of the existent, operating like a great digestive process, becomes a placeless anomaly and is subject to expulsion, banishment from politics.

VI. The normal and its anomalies - that is the real structure of binarism.

VII. Women become the other, the anomalous, the defective of men; non-white people become the defective of white people; LGBTTTQ+ people become the anomalous of heterosexual people; people with deficiencies become the other of healthy "normal" people.

VIII. With its colonial preconditions and its patriarchal public sphere, modernity produces anomalies and organizes purges: it renders norms positive (in the Law), quantifies offenses (in courts), catalogs pain (in medicine), patrimonializes culture (in museums), archives experience (in public files), monumentalizes memory (in protected heritage), essentializes identities (in global multiculturalism), commodifies life (in business), mercantilizes the earth (in the global market), equalizes temporalities (in official history).

IX. It is in this way that modernity, with its state born from patriarchal genealogy, offers a remedy for the evils that it has itself introduced: it gives back with one hand, and in a degraded form, what it has taken with the other. And at the same time it revokes what it seems to offer.

$\mathrm{X}$. In this context, radical difference, which can neither be typified nor be made to serve the colonial-modern-capitalist pact, cannot be negotiated and digested, whereas in the communitarian milieu of the Amefrican ${ }^{1}$ peoples of the Americas it is constantly negotiated and concerted.

XI. The expulsion of the other from the horizon has led Europe to decline. There is no intensity, no drama, because drama can only arouse from a limbic border of an existence facing the limit imposed by the difficulty of the other. Without that tension, European imagination has declined and its creative drive has also waned as Europe has become encapsulated, defensive.

I have been saying lately:

the first victim of the patriarchal corporative pact, the first victim of obedience to the masculine mandate

are men. 
The issue of Europe replicates this power structure: the first victim of the European mandate

is Europe.

It reveals itself once more trapped in

the eternal return cycle of fascism.

The signs are visible everywhere,

even within the social movements:

the trend of a growing "feminism of the enemy," as I call it.

I keep warning feminists:

all politics of the enemy tend to fascism.

XII. Europe has no other. For European thinking otherness and difference are a problem to be solved.

XIII. Europe has no mirror. It lacks the bad queen's "mirror mirror" which acts as a stranger, the other that offers resistance and a contradictory view from the outside.

XIV. Europe is trapped in a narcissistic mirror.

$\mathbf{X V}$. The items contained in European Museums cannot look back at the eye looking at them. They are reified, frozen, taken afar from the site where the stream of their life was once flowing. They were kidnapped from the flux of their own transitoriness. Incarcerated beauty.

XVI. In Europe, there is no right to the contradictory, I mean the radical contradictory. Europe had strived to erase the other from the surface of the planet and now it expels it from its own territory. It rejects the "face", the "semblance" of the other, in Levinasian terms, and suffers the consequences of doing so because the ethics of dissatisfaction, dissatisfied ethics, aspiring for less suffering in the world needs the resistance of the other and demands different points of views, manners and tastes to realize what it lacks.

XVII. The communal cosmos of non Western, non monotheistic civilizations has been able to receive and incorporate Europe, but Europe has not been able to open up to receive the other in its core. It has cannibalized others instead of including them together with the extent of their radical difference. The communal cosmos operates with a para-consistent logic that allows to accept, to adhere, to host incompatible believes and incompatible cosmological structures. Europe with its monotheistic neurosis, neurosis of coherence and control, cannot do that and expels difference as anomaly.

XVIII. Europe lives the fiction of being by itself which leads to existential insulation, boredom and decadence. The void of life results from the historical project of The Things in opposition to the historical project of Ties. The first builds individuals, the second builds communities.

Since recently,

I would say the last decade,

the moral argument is not an argument anymore.

The world has become cynical.

XIX. Capitalism has its theology. Its theology is very similar to what Hannah Arendt called ideology, ideology that naturalizes the defeat and extermination of all those who do not fit in the values of the victor, the master, the conqueror.

$\mathbf{X X}$. The moral argument does not convince anymore. That is why theory has become urgent again. Only a well-constructed analytical argument goes through and convinces.

Transtext(e)s Transcultures 跨文本跨文化, 14 | 2019 
How to open up to learn from others without reducing them to the same by means of universal equivalences, without subjecting them to rationalized translation. It is urgent to find out.

\section{NOTES}

1. To use the precise expression forged by the Afro-American thinker Lélia González, too soon departed.

\section{AUTHOR}

\section{RITA SEGATO}

Rita Laura Segato is Professor of Anthropology and Bioethics at the UNESCO Chair at the University of Brasilia and Head of the Anthropology and Human Rights research group at the National Council for Scientific and Technological Research in Brazil. Her work focuses on the issues of gender violence, racism and coloniality. She has published numerous articles and books, including La escritura en el cuerpo de las mujeres asesinadas en Ciudad Juárez (2014), La nacion y sus otros: raza, etnicidad y diversidad religiosa en tiempos de polititicas de la identidad (2007), La guerra contra las mujeres (2017) and Contrapedagogías de la crueldad (2018). In 2017, Rita Segato won the "Premio Clacso 50 años." 